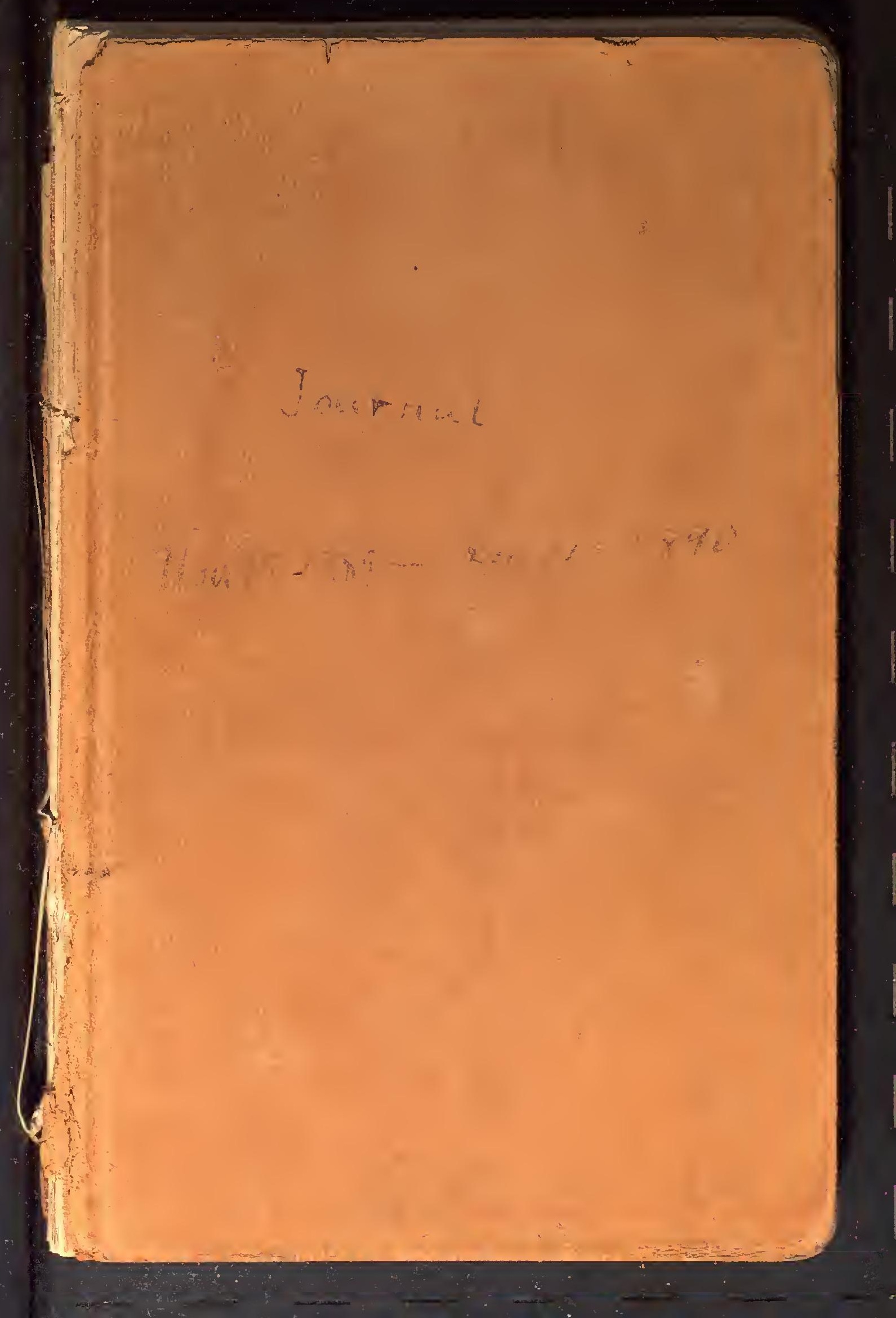


Journa

Vernon Baily

$$
1889.1890 .
$$



Nov.15 Lift hogales (Arizona) at 3 P.Mn. + reseled Benson of 10 .

Took the east bourd Tain + warked Wiloox at 12 PM.

"Ih the tran of Dos cabrooss - ins Howds - is 15 miles S.E. of Wileox. Had to wait fer mi tinik o took a traup aver the fldin. Slot a young Sfermofililus ofibsema of a hephs Texencis 5 a Covis exiftahens F some Ammodranus. Found lots of oles + trackes of a swall Difodonnys or Difoches, tralse of Mines! Saw about 8 Lepus r mastly crifroluens, trough o heand on eroak of the heavy, onttrial sound as conmon in S Let Loke Vady. the voiee of creffotmens is fire $x$

the country about wileox is flot 5 rather frase. muen of it is comster oor with allealie. the midely of the vally is covereal with oolt yos,s, Fanther Paok then an Yroeas, like angustifolia, t a fine Laved Actemesines There are low hountains all acourd. The two heads of Dos Cobesos an inf Hain viun to the sis. 
Pov.17 Eurday.

"18 Got my tumk het fornd the stage cles vat ajo to Dos Cabisos untie toworsour, so went huting.

filled a Kefurs sylvotien o name birds. skinned these th the se 18 traps. Cold nights 5 fbasant days.

- 19 Only oanght one Yommonys o one Difodofts. Skimned these r toak th stage for Das Cabesas at I P.M. Arrived ther of dack. Dav Cabesas is in the fool hills of a group of bow montains with no vegetation or aninad life. Altritide 5300 .

" 20 Aunted wast all bay, killed a Lefurs sybrations, a 'S. Gramunusus t some hinds. Set tocue teaps but could art find nuoh aigns of gaine. The country is froefuely Weathes cald. 
Nor.21 Caught 3 Difodomp, \& Onphoums, a Neotama, $\sigma$ a Hesperouns In P.M. went 2 miles down the road Toward Wilcox $\tau$ explored a cave. It does nat extrude far, if full of boles 5 erodes that sem to W alive with Neotamas. Saw one Bat but could not get it. picked of half a hetfull of bones on The voters. Thu are an immense sight of bones on top of the dirt, but the dict is damp 57 could ind vo bones a few inches blow the airbase. they seem to have bean bought the by owls. 2eould find wo fleets, bat then is ont dub g own all th soles. the cave is in a hand, the limestone. It is about 30 rods from the rod on the

Sow very flew binds t no manivals but Babbitt ra few Praise Dor ps. Reset un tops o are de of the atkins. A very pleasant day t wat to s ald for don port. 
Vor.22 Qanght a big Difodonys o sour Quplomps it a little Difodomys. Stimmed these ost some traps. did zot hunt zumeh. Exflored a shaft to an old nine buf / rund wothing in it. Canght a Prainie Doy.

"23 Canght is Peroquathus flavus - on like it - o 3 bie Difothomps 2 Omehorum. Kithe a pain of tharhormmotus criasdis. Made op the olius o Wunted a little A very pleasant day st warm evering.

“1 24 Sunday.

. 25 Packed of r wrote my refort.

"2le Cave doan to Wileax - 15 miles - in A.M., 5 in P.2. oet 28 taps rhmited on the plain about Wilcox. Found nothing

Set the traps for Perograthus o Dipodop mastly. A warm pleasont day but rather windy. 
Nov. 27 Caught 2 Diferdops o 4 Perognathns flows $\sigma$ a throws skinned these o packed sent them by mail. Wert the mu Wider votes. train to Deming, H.M. cold in warning t wavering, hall

" 28 Reached Deming + daylight $\sigma$ put if of the ST. Yours Hotel. Took traps a went down into it valley $t$ set 20 , shot a Lipustex. + a fumes. The a andy fast of the rally is trick beaten draw with tracks of Rath ts $\%$ Difodops ( $P$ ). The mid deaf the valley is a bandy region, cooled with tall peas o a $2 \mathrm{w}$ big wads. Higher of the soil is Hardin covered with serubly requite. There as wo mountains are all around. the sally istroad o quite bol. Deming is a lively little P.R. justin Town ta joint of ruffly for sames * ravohshen. Thisivet is dry. wells are def, + these are about 50 windmills in Town. 
Tro.29 - aught a Dipodaps t a Nespenouns - a Perognathus ofoehe t a Ceonus o slot al Cotton-trilt a Buto F. Caluns $\sigma$ 2 Oraseafts 2 Carfodoens m. pritalis tanCmphisfiza ti nuodensis. Sut 13 wou thaps, wabing 33 in oll, masth for mies $T$ Difodops on the axuly land along the dry sions chamed. Found some holes of Stemk on Bodges, but they wise hult of Raffits trades a no ust to set traps of them. Saw lats of Rathits of toth finds.

- Mat rack to hotel of 12:30 in P.M. wade up the sebins.

a cold morning + warm lay.

"30 Cavalt 4 Didopos an Onjelomps $\sigma$ a Veatouna ra Cettritail.

Tho Pergpothus ran over sofset $r$ opung my hops, bot would wat oft in then. They are very numerons bat L dont know low to cates them sucensefistly. Killed a few birds. Put at abiunts in P.M. I

A cold mosning but wand ay. this is the last day of tor.t my oatelogus shows 103 wanual skims, ofotort 30 opicies, foith wowth, 2 tawe traveled 800 miles. 
Dec. 1 Sunday, warm but doudy $\sigma$ lraks lik', rain. Went to my trafis in mosning o got cane Difodops o Empehonys od Perograthus of ache.

$" 2$ Canght 5Difodors ra Aeaprerong - a Peronothus afrach. Rexet the tops eacefully 5 tried raiting as that is what they aesm to feed on. They dout take vait 5 sem to $w$ ofreid of the trafs. Theis traoks ase numerous in the sand but 2 howe anly found one lole whase they live. rave anght $s$ at that bole Difodops are not so eary to eateh as the litth Difodomis were in Mexies a of Daslookesols. Found a big stiok house of Nertorras $\checkmark$ set traps for them. Casvid enfthtenous ase numenos acound town ofud with the hogs in a stoek yand. They are as trame as the dombtie doves! At thateme fion II actaek till dark to skin o fut ap 15 manmals. Warm $\sigma$ sow elondy. 
Dee. 3 Danght 3 Difordops t a Poomys ot a Heofuromys l. noveriensis. Reseft baited the treaps, will hy one night more to cateh Perognathus.

In P. II went rut anoorg the merquit brush E. of toun. Fourd a few binds o bilbed a Thyostharus, found loles t trades of the big Difodomys * some little Perrquathus boles! Saw lats of Rabfits of foth kinds. Saw a Coyote inmonining. tat rot wearenough for a stat. Warm in wasring o warmall day. Sour 3 lizzards olot one.

"4 Panght a jeomps $r$ 2 Xifodops. Zooth wh thaps $t$ in P. M! set them out oul highes ground east of toun. Shat a Strermofinilus spilosoma. tave had 33 thafs set for a meets

Isied sumadeling sorne cyclome trafs so as to Qateh Prognathus. They are of raid. of trafis $r$ dout care for cait.

A arainday reloudy. 
Dee. 5 Songht a Perorgnathus in each of my thr nuw topps t nothing in The other 13 Cyoloue Tiaps.

Canght a Difoders a Difodonys chesti (i).

thade of skins $T$ wrote some. A pleatont day.

"L Canght 3 D ifrdounp deverti o

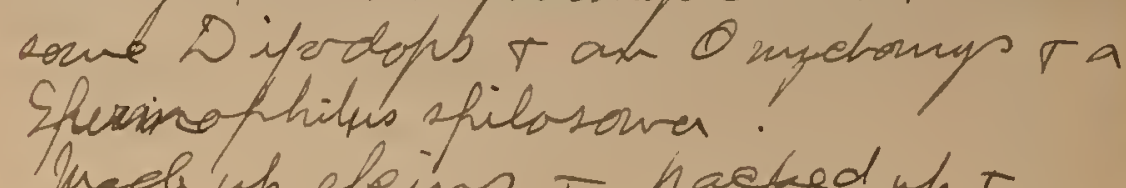

moch up eleins T hacked mp T am uody te start for ElPare tright. Awarm, pleas asct bay, sow eloudy.

"Y Rooked SlPaso, Tex., at L A.M. Got rreoppast thene went down to the siver to eer low deef, the wates was. Found The fed of the rivn dry $\sigma$ grow up to willows $\sigma$ weeds. That outhes the roat hif. gpt ectled at a fatel tinght a runte $r$ some ithes thinep that 7 was in meed of, made keme teaps o wrote littris,'s so dief nat gef mush tive to hent.

A warm day but windy odusty. The eermetry is as dead $r$ dry as it oould wul be. 
Dee. 8 Sunday,

" 9 Went down the rives flats stout two miles then out oo es the high es ground to the S.E. Found a fen fold an the flats that sem to fe of Perognathus, sit traps of these $r$ some no re traps for Difoodes at the edge of the valley. above the rives flats. It is a bright + petty Evergrem, lat stints.

Saw very fur birds t no manuals bat Ratites, Lepus texcamis o sybatiens were com tho on. Ramped a long way vat tine mich sign of life. $2 u$ P. Mm. took a tiff arturo in the hills 1. of tours. 'et pome traps $T$ tort a Lamias with a pale gray 2 s evening obiumed the Zamias $r$

A warm clay but windy $r$ the ain full of dust. Could hd s dy zee pesos town. The sion is dry $\mathrm{T}$ water in tho well o is horrible. It taster like old dirty soapsuds $A$ has a tad effect. 
Deelo Canght z Diefodofu + 2 Tanuas (harriail) but wo Proquathus.

Set more Taops.

A cold nowning wasm day, hotwindy,

"II Acold warning with a slim of ies on ford.

Caught a Difodomm ordi r a Difrodes ta feperoums + n Neotowas r two Tanias hasrisi. Wothing in sm Perrguathus torops. Hove obout zo' just for thern.

Haive in all 40 teefs sel but do not eateh mueh. Famped oven the shur of the morutain butt did not eee a. Taunias. found two in suy traps Though.

" $/ 2$ I warm night.

7ound 3 Perognathus flaves in my rafs or a Difodomys Ordi r a Noctoma T/3 Zamias haverisi t a Hespuromes. slat some birds. T a Lefusturanus. Went around over the hills cane dowm afore the smelter to the rives.

Found a gord place to eet traps oven in a tasin.

a hot day ow breeze. 
Dee.13. A warm night but 2 orly careght one Perograthus. Canght la Difrdops $\sigma$ 2 Difoderum ordi $r$ a Hamias $r$ Geomys. Part of ruthafr are up on the molutain N. oftuon $r$ pait down the rivenon the ilatio. It tabes me oll day to go acound to them or sit them orrs, bitlo eateh eo littl that $d$ can fut if of in the eriuing Avother evasm ddy, faicly lot no wind.

"14 Canght 3 Perorgathus flavens o two Prognathu, protbably, obsenust two

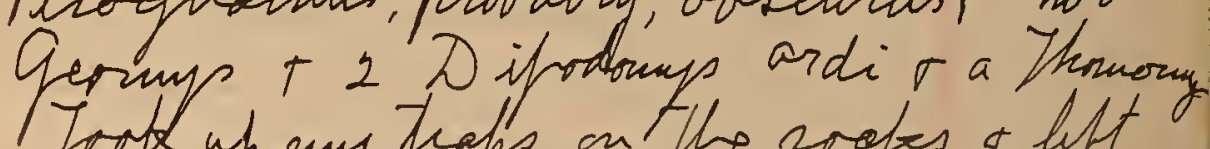
Took up eny thafis on the rootes o left out 23 down on the plat, wostly for Putp of 10 steins today radded two sheies to my list of mammals. Killed a Couns etyptoluens tathen. A wasm night o that day.

11/5 Sunday. Trale a Purguathus

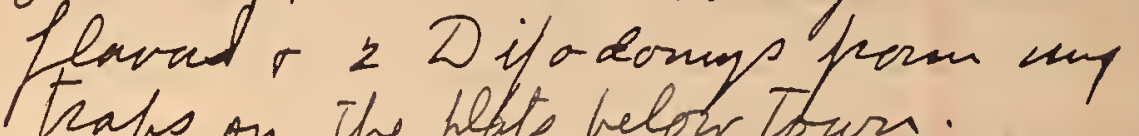
traps on the plate helour toun. $a$ wasm night $r$ pleas ant day. 
Dee, 16 Took up the last of nu y traps an the flats 2. of town? Closed over the ridge N.W. T sit so kaphs in a little valley about 2 miles from town t roobobly 150 fut higher. Set come traps among the voles around the valley. Kill e nothing. Seared a Crypt out of his bed under a bunch of Las shea mexican in a deep wash Duly had vo .12 shot in un que $\mathrm{T}$ so did vet shot? A strong wind pan N.W. all day.

"17 A cold night, no post did not upped so catch much but got 5 thomongy +3 Difodonup odis $\sigma 2$ Tamils $\sigma 2$ Perrovathos, with sting sumps, $T$ ais Ompabomps San 4 Coyotes Trashes uh on the hills. sunned to th hunting Chifummes. Saw 3 Chifmuntes, stators. A pleasant day, not it.

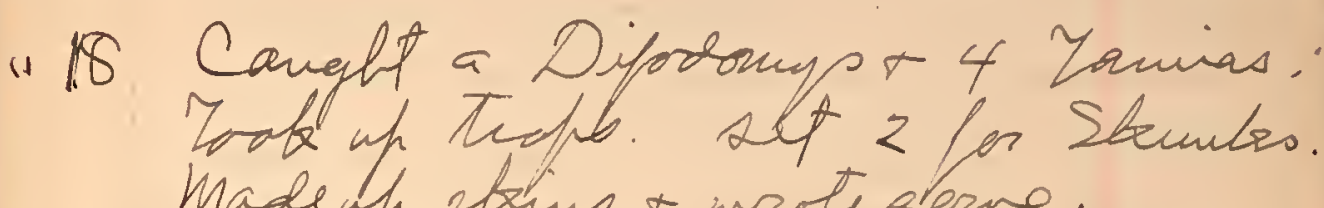
Made ap stirs a wrote erne. a cold warning t warm day. 
Dre19 Canght a Strunk but did a fod rot in slooting it $\sigma$ it sfrited itself for a ofeeimen. n-aved its stoull. Pasked o ent the shesinens + faobed my trunk + finished sofact.

"zo Left alpaso of biso A. Un. A Jold wasning $\sigma$ a thin seale of ies

Followed the Kio Grande vally down to neas Finley, thin wound alound Throvgh "Fadllands " till we came up outs the wese at Finley. Theres the ountry is a.rolling flain with some peaks o savges of bow wountains. Lt is dry orather vare yuesas are abundaht, the talf forms of baceata $\checkmark$ angustifolia. Ther ace sowe Cacti $\checkmark$ low cuedquite $\sigma$ Larea mexieana is abundalt. Rot a the of ang bind to be seen, qrass is cover. Ther is vo wath $\sigma$ to stock. Wo one hives along the R.R. ofter it leaves the Ris vally exceft of station $\sigma$ water is hrouglt 5 them by the train.

Sierca Slavoa is eomfased of a defot, a stour soloon oowbind, a fottl, t everal duelling loices. In P.M. Inntedt set hops saw 2 Jakk Rattits a Shrike o Auphishiza. Filled nothina. Set IY hapo. 
Drest Went the roundofmy theps in A.M. I

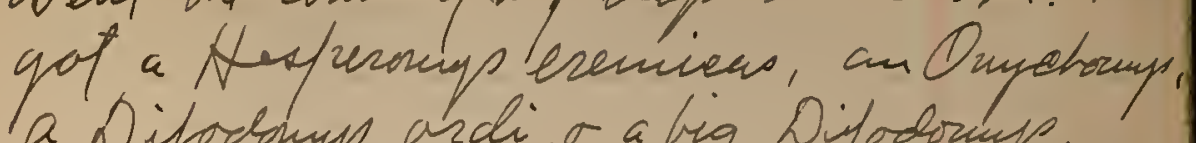
a Difoobump ondi, $\sigma$ a big Difodonup, a tipus ofluations, Lad P.M. canght a Cyromup hob. I Itot a Lifus tuxamus. Whit over the lill worth of town. It is roeky tatout soo fut hingh, then went lout on the plain. The conntry is dry flains t rooky 15 miles vorth of here. A cold, wivdy night t worning t rot very wasm oll day.

42 Zound a Tamias +2 Difodomys andi +2 Onyehonu in my teafs. Met Plof. W. A. Strewsurity. (dnt know low to ofill hismame), who is in charge of a stat Geologieal Survening party

Got rome information from him $T$ had a pleasunt clat of an lowr. a warm, pleas ant day

" 23 Canght une Ondromis o 5 Prainit Dogs. Topk if nuy trafis from the rockstan the hill S.I of etation $T$ aet sowe wou an the flat 1 . a coof warning o warm day. 
Ds:24 A warminght t wasm day.

Canght an Onyelowy, 2 Diffodomp ondi, a ketouna, a Geomin, a Thounowy or

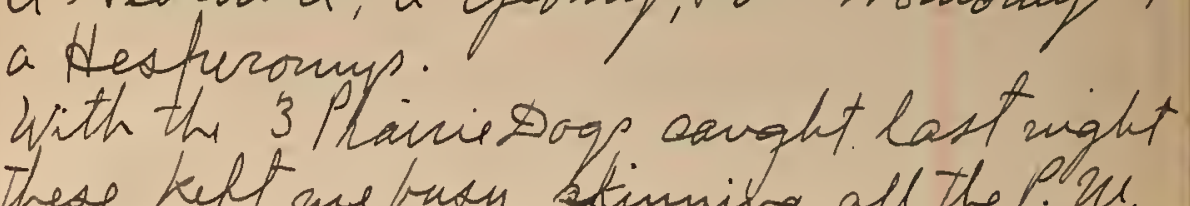
these keft me busy etimning off the P. W. Didnt yet wloft the teafs resct, but set mast of them in new places. killed' a Shrike + gaw 3 Amphisfira b. nevadensis.

- 25 Then say it is Christuras but it is lite a blay in early September. Th toys cebbrath with ficerabers instead of avow-fallo.

Canght a ba Difodonns, 3 little cues, 2 Onyohormps a Thonormp. Modich ativis in P.M. Didint do a full dayp work beeencse it is Christmes. "26 Canght a big Difodouns o 2 littl mes $\checkmark$ an Onvelanp. Killed 3 Otoenis 5 an Auphispliza knevodeusis. Wrode if stims o hunted some, bat Drioflets 2 Ravens rut couldw yit a oht of either. Warm t some cloudy. 
Dee. 27 Caught a Prognathous flares(?) +

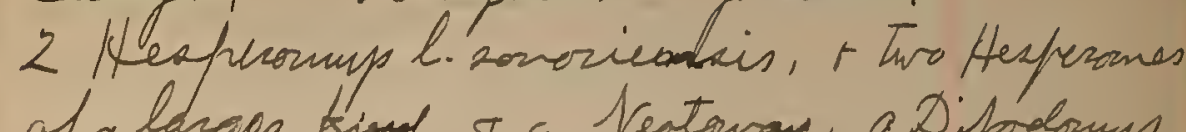

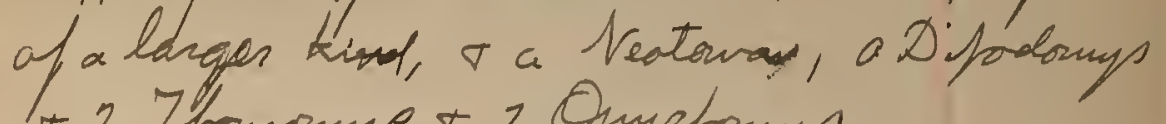

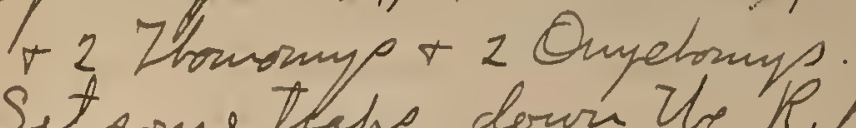

Sit tome traps down Ul R.K. east t lo fe to gil wore Groups.

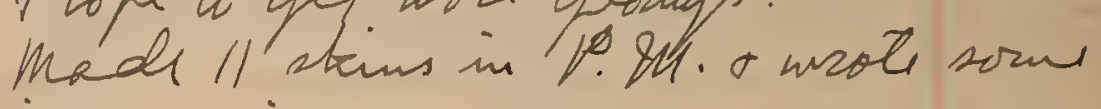
un evening:

$A$ little ices on water in morning, bat warm all day.

"28 Caught 2 Howounf ta Difolonys o un Anjeloomp ta Hespermus, but wo thing that 2 wanted. Tootle op traps. Saw a Coyotes. It lad been at a dead cow that the ears lad killed. made of the steins a packed the dry.

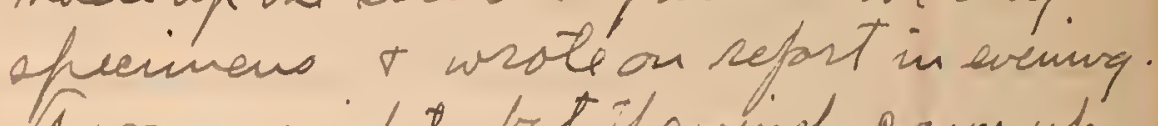
A warm night, bat tho wind e aver of in warning t blew a gale all day from The 1., cold in wining.

"29 Sunday. $29^{\circ}$ in morning, wind from the east all dat, cleat cod in. herring. is going tic be a cold init. There it are aced here 870 fut def bat the water is four not mush used. Quoter is bring drilled $x$ is down over 800 fut but vo water yet. 
Dre,30 Cold t char in morning, 14 at amines. Left Sierra Blanca of 11:30 9.24. Followed the valley all the way io Mort Wto. The valley is grassy small brush r yuccas in places, Inowates r not mush ster. Prairie Oof numerous all along. Saw one Yococeyx. Sow y antelope near encarta. char 5 mushing but e old doll day. staid of Marta 30 minutes o roots the stage for 7.. Davis. - 22 miles N.E. hooped then ot 7,30 , of ar dank. Hod a cold ride attu a fain of bitt le Mules Saw prairie Do op ta bot $\mathrm{A}$ Antelope trades.

. 31 Got a fry o tarted up the mountains third a face to stay? Followed of the Limbic Crest about 14 miles to Mr. Files Rales $T$ conchoid to stay the rs. It is mas the pine timber there are ceresin o ales 7 cedars o Pivon/ines all a could. the country is rough o sorry. 


\section{$\angle 890$}

Fan. I Staged all night of Mn. Finleys tin wasnirg staited baek to Davis. A windy day rode fast $T$ raw nothing to shoot. Paoked uff what things I nueded for collecting, wrote letters, + got all ready to leove 7\%.Davis in masning "2 Left my thing it lotel te be brought op by staited frok wh the nountain soot Found a lot of progp tadfales in a fool of the erukndar Dovis. Therelk in running a small sheam from anile above Dovis down fast the past. Saw Carge flocks of Otocaris t tongphurs hom Davif of to Dolans rawon, 7 miles obor. Slot a Siala mexieana $t$ saw wore t some that were evidently. aretiea Found a large Praicie Dog Tons about 3 miles abtore Dolans on a base sidetill $\checkmark$ valley. The Docs wre numeroust thisk. I slot one old mols with larg s protruding tetisen t a strouqudos, like an ald toar.

They wen tome t \& oould howe slof wou of olase ronge. Saw averal S. but failed te get any. The oftronon wes washu $\sigma$. They were ont ou the rodes sunning. keahed Finleys at 5\%.M. with a ldure kner. Walled 15 miles but took it slow came nfe obout 2000 feet. 
1890

Jan. 3. Mr. Finley say p that a man was up here last summer with a barometer $\%$ placed the altitudes as follows; 7\%. Darts 5000. Finding rand 6000 , the hight feat of the Davis MSs. 9500 . Probity Darius
rawoh is 5500 .

Hinted some but did nt bring a large ruffly of annmmilion with we $r$ so dicing hunt on far or had. Fill d a large gray Mathis, new to sue, it serene birch. The beam that I expected to bring of un y things today staid down at $7 \%$ Davis oven night will wat he af till towarow. Weather cloudy $t$ windy 7 wat mush game out.

"4 My lips are very sore form siding in The wind 5 from al cold! I little while out in the wind made them ashe o swell $\mathrm{r}$ my face suet; to, as the isntmush me mi hunting,' staid inderars most of th day. In y things did wot rome till about In evening skinned fir do $\sigma$ arsenieged the other e bins. killed nothing bat a few binds. Un y knee hurt. when 2 walk mush. a cloudy, windy day, fogey in morning. 
Jan.5 Surday. Hod to atiin therest of un binal to teeep them proun sfoiling Atbegan to raim in P.M. T keft of a drizgle the cest of the day o might. Whold doy went out o tuel a woryon viroinams wh a pinus edulis oldont 2 bigh. The tis was binty morly, to the orom the tort was vearth tos sitting ou lines of seemed to be ferfeetly at have.

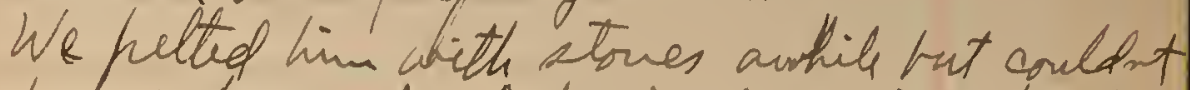

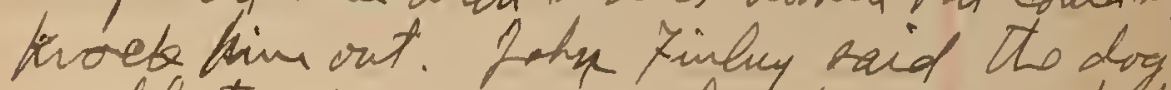
would tec him again clateby if we shbo hims out, so as d waited to werime elims a tine, I went of or, when claset thinghs diofued down past me Thoogh the himbs to the yround! The ground was otony s he out ran the dog T re veres am him again. They art gumerows hne $\alpha$ Finlys Lave eanglt a number when th loof tues them. are caid to always the truers go into a bole in rockes.

" 6. A warm dank norning, cloudy s stit. sut traps o killd a gray hathit to canght 2 Howomys in A.M. Lu PM. went of thr wounteins to of of

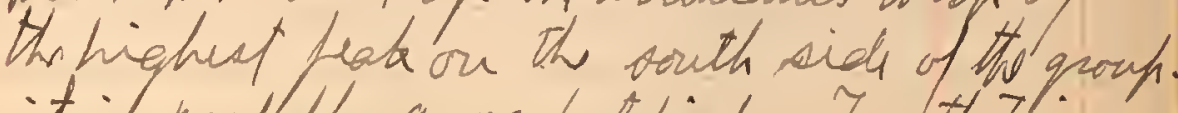
it is mototh 9000 ful high. Fo thithint Llad it was a bing clinte o the amenent 


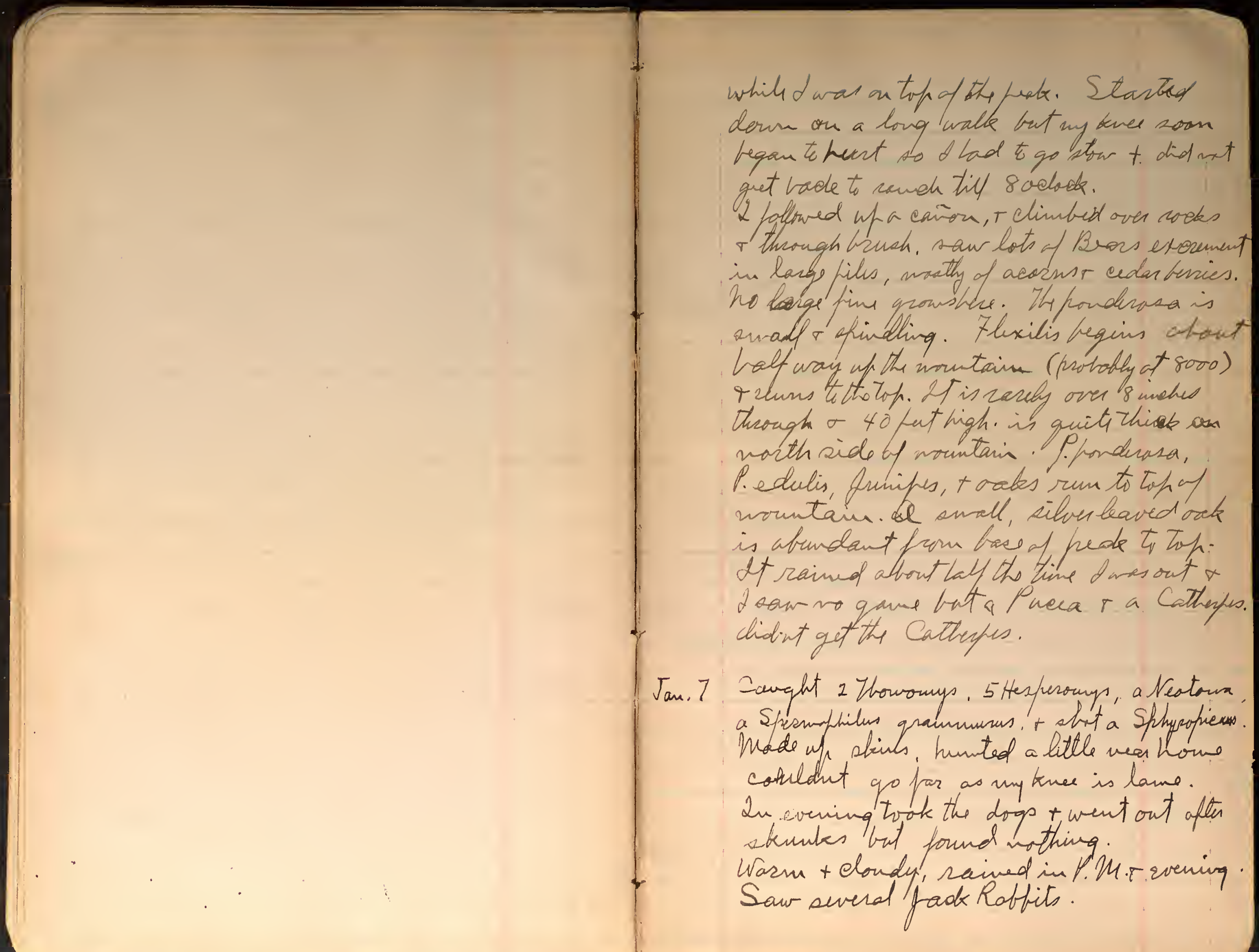


Jan. 8 Canght 2 Heafunomys 5 a thomomis is kilbd oome birds, Hunted, at traps, made op the ekino. Zrampel till eleven oclock in evening with the drap, bat they found wothing.

Cloudyt windy mast of day, but ws soiva. Clecered up in everiing

" 9 Canght a Wroeyon viginianus in a that sut ot ble in vocks. If was an old Q +veryfol, a vo. o sted traph held it by two toes of a fore fort.

If gat in the thaf. the pirst night ofts it was at, o It think thay lack thil cuning of the knd 7 ols.

Canght a Ylowoums a a Hesperomys of shat a few birds st a Lepus texains. reat my toofs, made up the abius. - hunted.

a char warm day, bat found vo S. quanmunus outi cri nodes! the Buteas

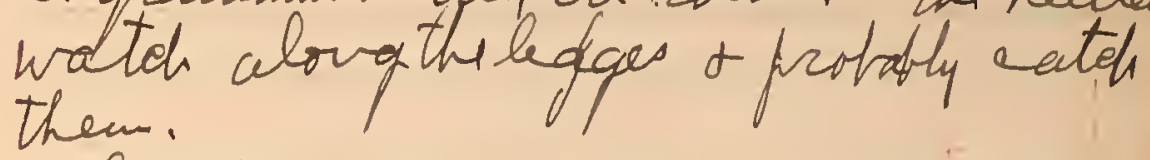
cloudedup in evinng againa. 
1890

Jan.10. Caught vatting but a Hespersmep a Veotana The wind flew a gale mitis noon ot then r named hand till 4 P.M. so I did vat hunt any. Went up the canon about 3 miles with the Finley boys $r$ watered for a Bear th ot had been editing a dead cow. Sat in the brush prom 7 code till 10 , but nothing came. It was bo desk we could nat sue to the cow, 30 fut away, was cold watching. Lt is probably wild cats or Foxes that eat it instead of Bears. An going to Ty foison now. While siding w th + canon, wee taw a large Blacktail buck ra dot standing on the side hill oboe us. The fuck was a magnifician fellow, with big harms the was very back colored. the do was lighter. They were to far for a sbatogun or the fellow with a rifle missed them.

Therein has filled of all of the rode tanks + There is pesty of opera water nom.

- Il Caught a procyon virginians $\sigma$ one Hesferouns, killed a Jay +4 Paltrifara. Mode wp the skims + hunted. Went up the canon of ont 3 inilesto the old sew mill, didst ese any goose except two Grails $\nabla$ failed to get them. Ido vat know the prices but they are cob Foo quails.

Clear windy, doused up in evening. 
Jan.12 Sunday, $25^{\circ}$ in morning s a little flurry of avow, windy raw il day. avow lew off.

" is $22^{\circ}$ at anise, chart still. Coldest warning of the winter do fan.

Fo ok a laser started over the mountains to see the country in the north aider visit the ranches o get Bu as abeillo. 2? Went up the cimon about 3 miles $r$ then dined the sight side a crossed the divide where it is 72 yo tet, measured by W.T. Canaerore of Was: Fallowed in ald Grit. road down the cannon on the other aide + readied In. Perkins ranch at I P.M. this is about as high as 7 inlays - 6000 fey Was welcomed by 4 hounds of the rust rf The family, After dinner went faith down the canon 5 killed a Repro aylvations Sow a S. grannumens, Birds \& Plants are about tho same as at Finley Pins plevilis $r$ th narrow leaved oak grow on the vas th side of the mountains high $/ \mathrm{a}$. the canons are brushy $x$ deep. The N. side of Livamou Peak is a firfindiaular fare

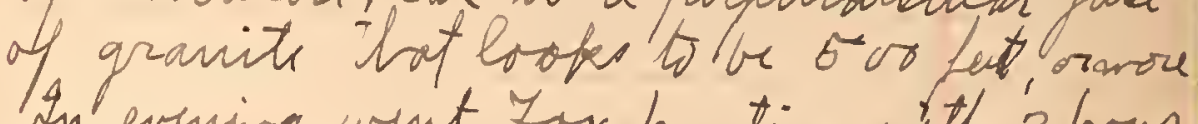
on evening witt for hunting with 3 hoys $\checkmark 5$ homos. Lt was windy. dry 5 the dogs could not kef a trail, o caught rotting. they ran two traobes for some. time o 
made lots of music. We plowed up r dom mountains oven broblu socles of ne arles toke our woks, Lt was dark t cold! Staid out till iso 9. U. Lt fard in e will for the work rust o hem the coos among the cooks. We coldest TIl which wan drops which eofro.

Jan.14 Could ut gut any Bear skulls of Mr. trains" They hod kith a number bat a long way from lome o did not sing in to atolls of fut one $r$ th rage smashed it. Could vat indue de hi. Perkins th take a cunt for un brand. Said wo one even fid a cunt for slaying under his son! Thy an sough but generous $r$ intelligent piffle as ak e most of the raven men? Drin. P. told me when $/$ could find a panther adult at i sarah 9 miles west of the rs, Mr.Curis, a 2 started to follow his Directions up one eaton g Low n another. killed a S. gram, o saw another. They were in a shutters place in the cavern where the eu alone t it was warm; west feuding under finite trees. The oukithd trot its cheek Touch pullof Juniper berries $x$ was very fit. Thought ra ot adult. Sow no un b birds or mull que of axypleived. Went oven a divide torn another cairo 
(Thomaskerr)

came to Mn. Persis Fan sh wont 2 P.M.

Found the bones of two Z elis r oft the soul of one 5 the upper fort of exult 5 the tail ore t scapular of the other. They hod the sabin of one, but Dm. pier was not at for me of o could wit get it. It was in fine plage, of a grayish from Both the Panthers were acid to fe of. Found a Bears stull, which is of a $f$ that fad 2. cubs.

Went down the Qainou a mile farther to Mn. Kistesus offer a Ben stull that was said ti be there, but could nt find it. Cams book into mill creek Canon $T$ then own the main divide home. The sem went down while 2 was 8 miles pour lowe with a normutan to eras a wo trail ores the top. By grad hove a did rat get lost r waked eur. Finlys of 8 rebel.

Rather enjoyed the tiff, ow much comity got conte bod sfremens, ant swed levant people.

fou i. 15 Pasted uh o went down to $7 \%$ Davis. colds windy, clear. 
Jan. 16 Came down furn. If, Danis to Warfa,- zzmiles, Faced a stang, cold wirel act the way, got chilled, oaw litth game, only' P. D. OOtooris $\sigma$ Longofuns r ove Rorbit. Ao nougal mhend come to Tours had a lot of little things to attend to a did not get my nepart finshed. nor all the ofeeinems seady to shih. Lee was $\frac{1}{c}$ on inseh thisk in worning rit tardly thawed alt day. Clewr windy.

"17 Paokedupt aent off. The sperimens, Fisished my refort wiot lifts ont my things keady for arother stact in wosning.

Q cold moning bat warmed if to a eompatably daty.

Didn't qut ine to yo nunting attiell.

- 18 Gat a tearn + alarted fo Mu Lloyd's flave in wornirg. 2t is 35 miles 5. W. of trafa. contry is at first rolling flaius. fien we follow down a vallys between ow hills with step, bace orally losking sides. I he country looks as thongh there would be foscil word, bat cond not find arny or learn of any. 
The qround is faich coveres in plaees with / caleedony, in lacoe + swall Lieess. whit r oreany s pinfl, wery pretty Grass is wostly soten of tho theoud rather bare. Thee is lots of frushwasthy thorry; as. merquite, ats elaw. * Koebectiva spinara, $r$ lots of cactures. Saw no trues on tho tiif exeept a few Inipherus virqinianus (2) on the nills Whar $1 / 2$. Lbyds $r$ how cottenwo es alme tho crek of his flace. Prairie Dogs! Pfromup lordovaciarus - cese numerow hounaif to the hilfy country wear koyds, also soles of Diforoups (ordi?) Lepus texanus i sybatients are very numerous is the budhy valleys, sovitimes 20 Laxamo in sight of onses o severd sybaticus. Colifefla squameto was commen. * a number of avall birds That I lad of X seen/fl sometive befor. Lloyds place is 4200, 7500 fect below marfal. There seems to be a gleat difference in the weother here, Lloyd rays the las been but one frasty worning this winter the country obtont lloyds paed is hilhy stomp r rattrerbare 4 ebveral aimuals do not seem to livehere an that weesunt, anch as Difodonys 4 S. dibsona. the creet vallylot flofds flace is 
pascow + deef o contains sowe timber + vsush. Ther is water in tho oreks in places but it does vat rum all the way. A coal wasnig at marpa but wasm ot floyds.

Jan.19 Sunday, found 20 mydonus t a Geomp sa thomp in my teaps. Took a lovg wally r saw a uroeyon viginianus $\sigma$ lits of Roffits o some quaib. A warn, pleasant doy.

"20 Canght 2 thosferomis ta thousuns $r$ sllt a Gnay Rablit.

Mate wf the obeins 5 set 28 tiafs thunted some. Followed up the ereek a mile a so. Found a lot of hed taild ffawhes in the cottowwords but didint kill any.

7 ound signs of Difodornys T Nestornas Tanies.

A wasm, pleasant doy, wind prom the N. in 'urasuigi of from the S. in P.M. 
$\therefore \quad J a n .21$ Qaught 2 Difodoumpordi $* 4$

Omjohoum + 6 Hespersomp 5 oue testom t a Geomp $t$ slat 2 Llmos sybrations Toue Lifus texamus o a Lynx +7 Butios $r$ a Sturnefla.

Cleaned gun + loadsd shells + made 14 sthins o skinned the rest of the small strff. reset th teafs. A plearant day, Clantwarm, Hare been rather basy,

the towbe eorne into the cottruoords by doyens to roxs?', slot them in enening, forud the limx in one of the cettowneds a slotit with 10. 8 slot.

Jax.22 A nies clear, eval mosuing, Canght a big, yellow smooth taifed Peroqnathus, (new). Canght a ony large Geonun, 2 Omselomip, o 2 Hesuromp. slot 2 hems sybaticus, Sit the teafs oors, made of steins, Went down the eañon in evening to set Skinkt Taps 5 got voeks oflis dark. the littl turtles were "unddling "in the fools r prop cioaking as? A irasm, plearant day. 
Jan,23 Canght 2 of the bing, new ierognothes, + 3 Hesperong l. Rovociensis, very pale+ a Difodohypt a Hespesomp eseminens. Took oth Trafs ot made wif the the stims Set 15 teps in P.M. wasthy for Peroomathis. Took a long teanf, we the liels tat qot wothing bat on ald sbull of a ken. oredged the ereele for frogs o found anothis binel of Juctle-soue shells bat wo frope. Exfest to stast for Marfa in marning. clocely with a trinikle of caim in PPXY.

"24. Canght 3 Hesperomp 1.2orosiensis $T$ slof a thovera! C. e. einuatas, put up abins, pracked of o mach out nugherot. Cleart jeisant.

¿25 Came to Mrarpa in a peary wagon, came slow $\sigma$ lunited $T$ fieked up stoves clory rood. Saw a houk that was protiobly. Faleo musican on a west in a lole high up on the face of a chitt.

Slot a Rothit that is in aize retween the two others got of Lloyds. Saw lots of Reftits r Prairie Dóp. Otrouis + Longapurs numerows.

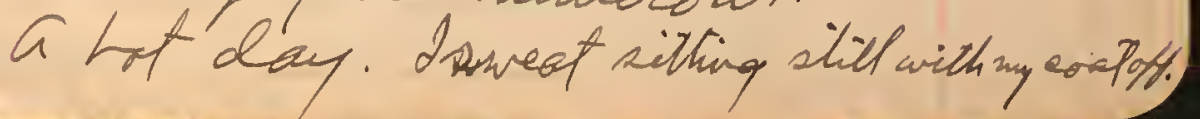


Jm,i le Sunday, weather Peasant.

"27 Packed up the seat of my specimens 5 sent them, packed ynjtunut or cleaned quin $\sigma$ loach a lot of chill o o left luria at 2:30 P.M. for Lavathy. From Marta tho R.R. rums over rolling, grassy plains covered in places with Yuccas!, no brush a thess. Prairie dogs numerous 5 all that were near enough to seeflainly were Ludorreianus, Afters riding about 3 a sunnites we cone into hilly country, a range of Dow, bare mountains exteveling poon $7 \%$, Davis, The road winds around hills t along ceroberd valleys t we be ain to go down a step grade

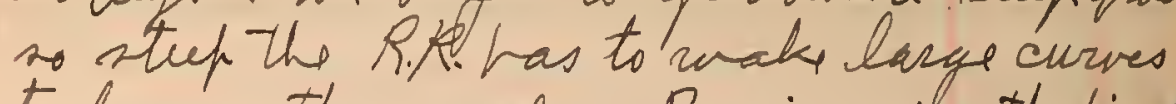
to lessen the grade. Pacino is the first station among the hills, is nothing but a station, but is in quiet e a pretty valley. There are a few odes on the rocks. The county lies not change much from the rocky hills t narrow, evoked valley till near Alula, where it is smoother 9 The valley wider. Water seems to be found all dory by digging. " stock is abundant at Hay mud the is a little erik, with small farms along it. There is brush + grass but wo timber. It would be a good place 
to collect the House hits, are neas, are a flat tiffied tunch of V Vare, socky hills. votley + makes great ourves a in lissen the tyrade. We soon hove the cruk $t$ ane betwen low, stony hills which seen dry r uninteresting, Rach Sanderson at 7 ocbeck stop fo suppes. Lt is dack here but the moon is shiming os strous the sama. bace, storn hills; as neas as ? can tell, it is the pame to karog try. Rooked' taurotry ot 10 P.M. 195 miles form Marfa. Found a ristausant where they have some beds in ane corner was pnit in with a Hade Kexan

Jam, 28. A nive coot moosing but vol cold, got out $\sigma$ vegan te qet arquainted with the toun o peofhe + sursonuding country. Found for a town a defo + two bitth tares t sabons conbined t ny restaurant. theie is a burefe of soldiess eamfed betmen town ot the sives.

2 couldivi hind the sives lill a man told the R.R. obout 40 sods pourtoan. If runs throvagh a nassow Cañon dout 200 fat deel The rocle is af limestone $\sigma$ is entints numuous side eavions by the wates. 
$5 \min 28-29$,

'L coming from forestry, to Del ki we were in the wight but lad a good worn. It is a very rough com try. The R.K. suns near the rios most of the way - sourctimes you can look down nco fat straight below you to the riven 5 again as high to cliffs over your head. Then are $"$ longltimnels. Parotid Saves is the mien t Lace on th south. The cliffs are grand, the the looked as far away as th stars. The canon is brushy 5 would be splendid for collating. Then ware surest good sized louses $t$ simeon ted a fire in are of the eaves.
There is a sandy flat along the sires wast of the way dour in tho bacon, som times cai one side t again sn the other. This is covered with wersh thess o plants. All an green $T$ flowers ace in Has sons

Thu are bots of coon Locates a skunk tacks along the rives. At would he a good place to collect, only 2 ho nat want to make bat one now tsp r want to make that where the fauna is charativistiv of the flat country south of the canon. this I will rot find until \& get fasten down, y fou all \& can barn Del lis seeress to mi the hest faint. The country at rove th Canon here is fare $\sigma$ stound dry Some kind I Prognathous seems to te common here. A Block Bears Bald Eagle are kit of a gabon as pits. Panthers one said to be numerous ores on the Peas R. Hunted mast of the day, filled some birds, took notes, s collected rome plants, wa thy ties in the avon. Cedars c araks \& Mesquite are common in cation, also. The Reausetion Hent on rocks.

The limestone is full of fossils. Went into rows caves fut found wo thing. A very warm day. Got some shells like these 
Jan.29 Came into Del Rio at 1,30 1, M. Went to Lotef r deff till sumise, then got out r hegan, Lothina stowt. Found myself in a strably, seattering lith town full of bush f neasas. The country cell around is flat onshy eropt some how hilb a mile east t a Hhe live of Mountains curay in Meries. at hast iov miles away.

Got my things to blef $\sigma$ stimned 3 firds that 2 kilhd yostuday stuffed the Lumx sbin tat a got at Hoyels befou dimes. In P. An. todk thafs o went out on a zond to the south. Fouvd some holes o lots of singus of sigurodons. set $/ 2$ thafis mited till sundoun:

kilhd a Cottontails 4 Quails 7 orme othes birds. Birds are numerous. Found a deef, sapid siver near town, Didnt kwow it was there before. The Ris Qraskes is obout z sules chistant $r$ did vot zer it. Fonvers ase flowing, sowe fields of whey are queen romies. The stalts of cattow $r$ coin ace on wast of the qround r eem To be the pinaifat erofp. Fruit trees are numerous, there seans 5 be quod chanes for insigation farms ase quits numerons. Warm enough for summes, Tues ane mosth bau, but flaits one qrem $t$ ergetables in all 
The Opossums tats are in a qroup, $\because \because$, with a young to erech teat. Two mose spots seuned to be rudimentory tato. not yt debloped.
Jan.so A tamp, nisty soosming but cleared op lepoenow.

Mod' 4 Qquail skins r Themwent tetraps. Canght a sperwophile, fike 13 hineatus, $\checkmark$ an O passum in a trep set at a bole. It is an old o t has 9 very amall youry in the fouch. each young has fast lold of a toof rkeifs clawing the wet, prom hais to full italy down closen. The ded ove ded not offerto finght. Caveht 3 Hesprowns $\sigma$. Iu P.M. went accoss the erede r down on the other side. Found a lat al fossil shelle, tow itles, killed roure bieds, a foand good loles for Skninks. Got all the thing plem but the Ofrosem in evning. A warm day.

ir 31

Coupht 2 Liqurdous o o Hesferomp, $\forall$ a Robhit. Shot another Rothit o zone birds, Moade wh skins t hunted. Saw lots of Rabbits int no other manenexeft secnodons, they sem to 4 quite dinimal: in P.MI Warcm. 
7sl.1. Caught a of Chassum + 3 sigmodom ta Rabbit. Slat a Golden fronted Woodpeeles, pat af sting T lumber. Went uh the creek, - San Philippe Cruckabout a mill, It is a queen stream, beefs sunning uncles ground T then boiling if out of boles, is winy deep in places, the watt is chen $x$ thee our lots of fish in it.

Cloudy mast all day $t$ a sprinkle of rain in wa ming, charred up obolus 4 P. In

"2 Sunday.

" 3 Took my traps * went down creak on tho eth side about a mile. Set 15 thais but did not find good places. saw lots of Cottontails + arne Possum trades. Shot 2 binds. My head aches $t$ my boas are make so 2 could only crawl along o got ry tired. dom wast of the thine took z fills, which aphinoted finely then Fold two cases of quinine. Feel bites in coining. Ht was dondyronisty all of A.M. tat elearedichat f pips. o was tot. Wrote serve litters $\sigma$ gat som snip. 
7.6.4 Taught a Neolowa tan Pebetodon 5 $z$ Heseromes, Got z Bots, atianolek bonse in Toarn. Hilld some birds. Put uf sfecmens in evinura, worked later r fregt to with in jound as do it tounght-The 5 is.

"5 Took a luneh + went dorn the creuteon east side to tho Ris Grande v down the sive aways. 2t is sodery alorg the rives obout s mile from torm, tr fieen trus grow along the flats. Then were wore finds down theu than Llave fornd befor, but wo sign of Siquirels. Found Fooket Gother ritl on sandy grand mear the Ris $T$ set thefs for whot man Is Arvicalas. The Haskbern hus an loaded with mistleto which has geat quantilis of bersies on.

canght 2 sfecies of frogs, stot a teal dund but could int get at without swinning odid rot awim.

Canght a spernofhite t an Nestoma ra Heaferomp $\alpha$ a Siqudon. Killed lots of firels. In ivining canght 9 Bats as they eame, ont of a hole inculold lons

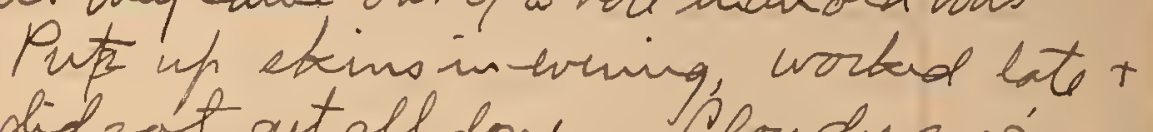
did wat get all doue. Cloudy nosing. wasun day. 
7 sbile Wunt to trafs down the cunle to the $R_{i}$. Canght a Ams tursenhus a tespresuyst a little Blaniva. Slot o Panibutio $+270 x$ Squinsels. Sfut a good

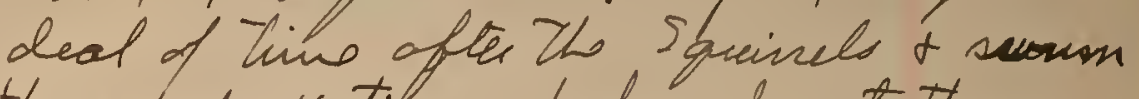
the cuelo 4 times before 2 got them. Got chilly + lave a sore throat te fay for it. Set 3 Geouns teaps made of stiurs t bequen on rofort in erening.

Weather as usual only damper in fouvoon, alwast raming.

"I Rained t hluw a gole in the night, the

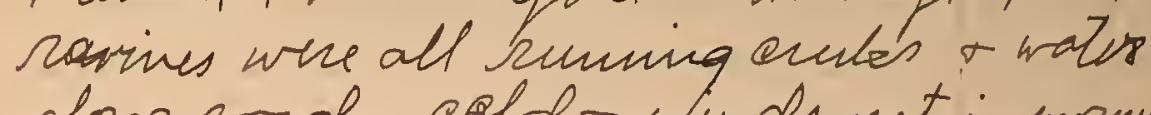
along noved, colds w whdy yet in worming. Got ont early, want to thops, caught an Achetoobu hut ro Pabet Gophurs. Tho sain filled uf tho roks $\sigma$ the haps wouldart spring, didinot slep to hunt ement hat bit a wothen Geomp teaf. $P$ acked ofecumens t wrote unevining.

" 8 Getalors 8 wents Geomy tiaf, caught ore fins speminen, Racked up $r$ finithed lefort $r$ ani ceody. to hane in mosuing. A clear hiagt t oold. some past.

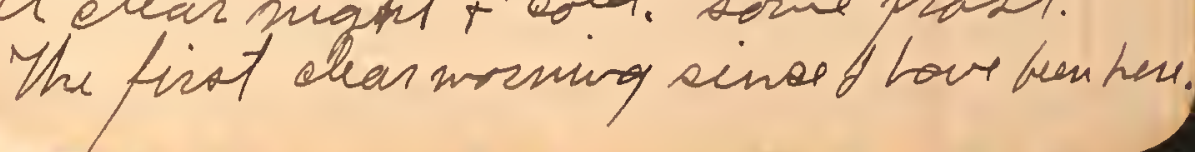


7sh.9 Left Del his of 1:30 A.M. r nacho san Antonio at 8 A. Mn - 1 To miles. the country is all flat at Somantovio ram ont of right of mountains for th first time for the first imine sines communing to the Blake tills of Doberta in time, 1888 .

Lt did not get light until the thainwas about 50 miles of Sanautonis. Hen the country looked hitter than of Del Riv. there were em all streams with meaquit $r$ ivergeun cols along then, some of the thess av loaded with gray famish mass. There are raveler st some farms Grass is abundant.

hear Sam antonio these are gored farms. vequtoble gardens are gree with all sorts of vegetables. The moguitis are in blossom r so cure some am all flaunts. Vegetation is mostly boon of in a rusting state. Yucca boceotas are in Mlaraem in the yards in Town. Lt is sunday, but a strolled about tour e mast of the fou sou $\sigma$ then calked on W. Attwols in, PM. INfant The not of the day with. in m. There are nome vies buildings in San Antonio the old Aline Mission building when, David Crovoltt was killed, is a fins old cum 160 years ald. 


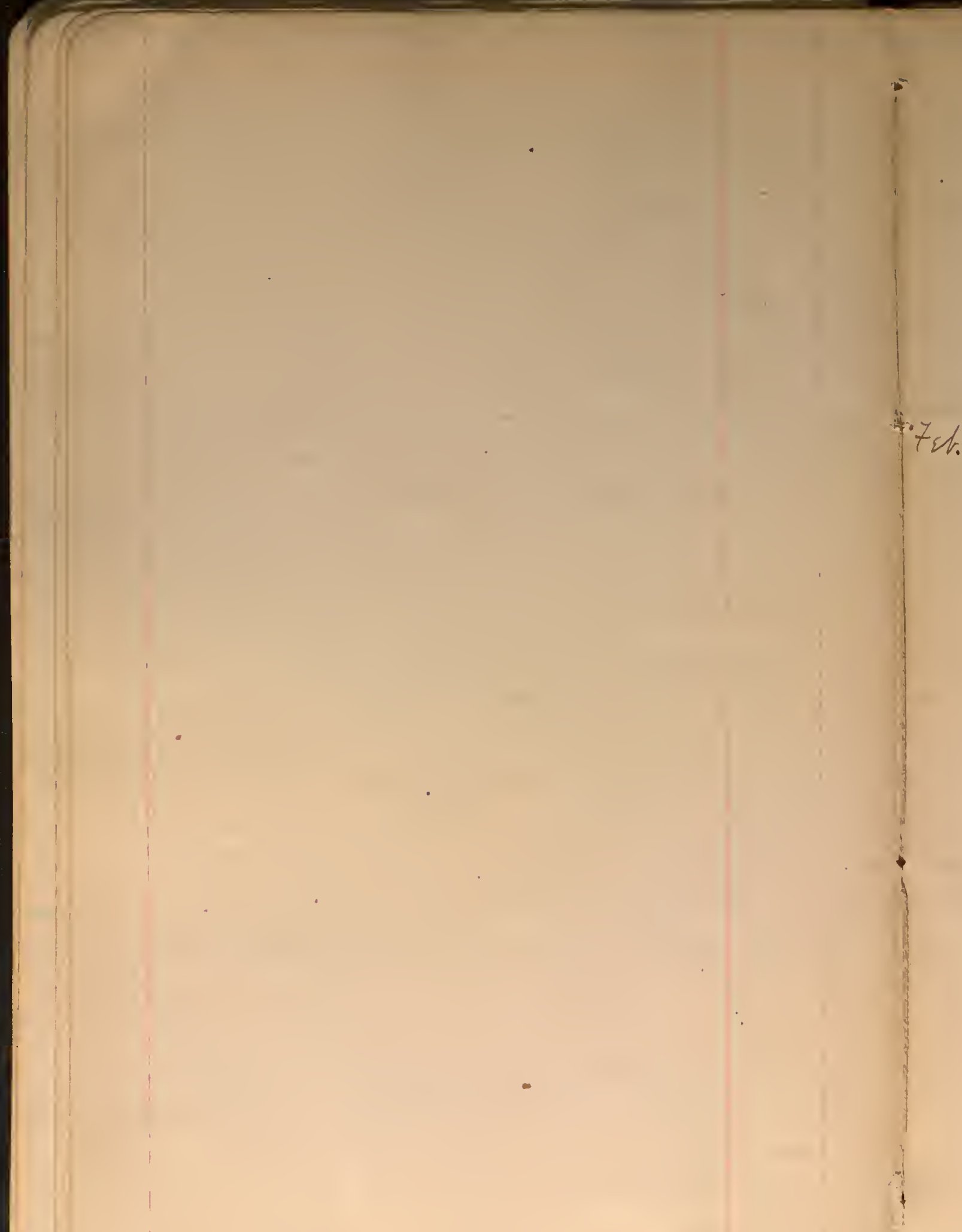

San Antorio is wiilt in the bush, it is flat - loasih bualt, snam little tumbleclown bouses. It is called thy sivest coms in Zexas but of do vol like it. there one lats of biras all over tome. The mooking binds 5 Cacdivals are trying to sing. A prosty cuosuning. Warm day

th. 10 Avather frosty wasning, woling 3 in aveession. Attrotes says it is the coldest opell of the winter. The ports are hight $\sigma$ it seems to wasm of quineledy 7 ound - lot 2 eould not have town for the woith unitif solede P.M. so ofter attending to my bogarage the busines, \& went tack \& fitwotur $\checkmark$ staid hill' 2 oclock talking with him $\nabla$ slowing him some about doing fild collowing.

Left Lan antruis at 4 PM. for hture by way of Austim $7 \%$. Wo th Kansas City', Qininey, Surlingtor, of Minneapotis. Eached Mustih at dente After leaving San Antoni the eorutry Ds ofen, sotling praisie with Inibes clenof thy streauns. The soif is dask r looks sich. Threare good, lares fasmo al aloud tar sign of invoption, liags eottoin fields are sumerous, ale corn- 


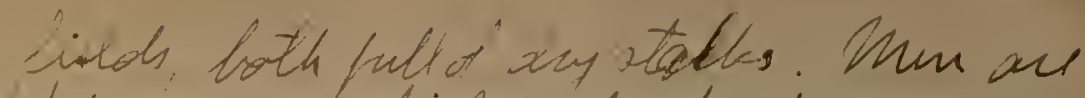
flowing $\sigma$ filds't whest are green,

Fruite tues are wandant + these are good loobing farm rowses. Bales of bottm are with if atroust the stationo aling the rood.

Lip oalas - muquit thes ysor along The stcearns, many of thy oolls ase loadrd with Sfaush hros's! In Llaces some ieined of cedar tue touns dense groves. Einee sunsise the weathn as him about usfect, not ino warm, but so it was fleasont with the eas drovser winderss ofen.

Fer.11. Came into F\% warth ot claylioht. This is a nies eity, seans wor like Minneafolis. The eountry around is al arling frainie * correc with good big farms. The paisis grats, whers of llastured clown, is high * thick o wilds a quod crope of hay that seums 5 he of arod qualiti. Whent tuilds are qrum. Fiedo of stavidue cothon - dorn statle as obendant 7 large. There au lots of birds, but 9 can vot toll Sturnella magra form reglista. Rowethes th Crows ar Crows or 


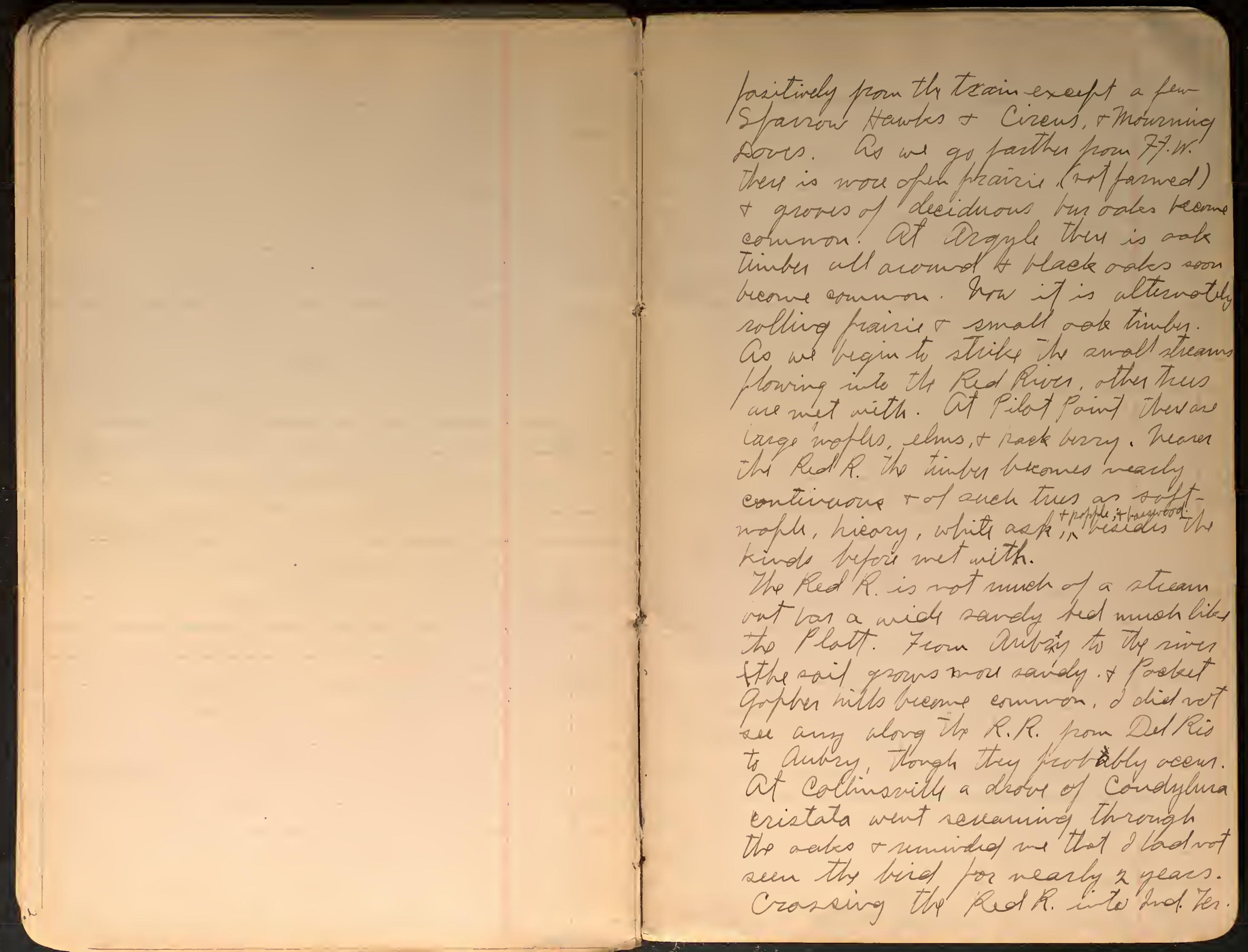



The R.R. asses through wovas for
some olistaves, F then ont onto colima

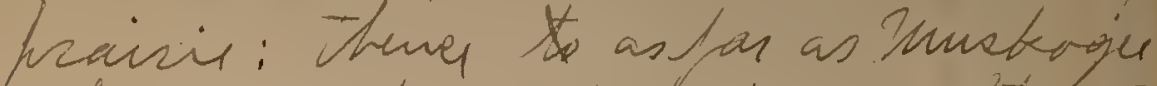
wherit qot dact, it was alteruol timber oraisi, with numerows swall streamis, In claus solling to again huel, oft Jassing Atokd, roday o

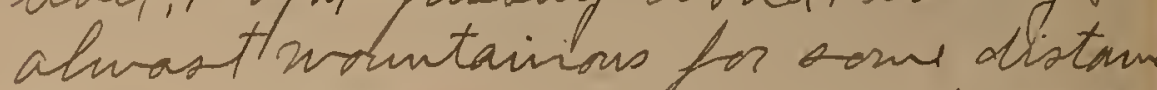
We seemed to cross a range of low mantioi: extending N.S. +S.W., covend with fines, cedars, $\sigma$ oales. Sumoohes aus com. $\sigma$ the first whit ineh was seen otten fasoing Saraunah. Some of the pines lock like Piivon. 2 sumbubend Prot. Cooke as me fassed Throngh Caddr, a little inure on the fraini.

The soil arass t timber are exolent all along the R.P. in Sud. Fu. Then an little touns sa fow facms o a litth stoek, fut 2 didntot Rer an Grdion. mither a saloou.

Lt was duct as we came intollnatogen at the Acteansos P.

Go fast in the warning of $7 \%$. Wo th t a reny fleasant day. A littl cettrs sui in Indi. Zu. but not moh ofts

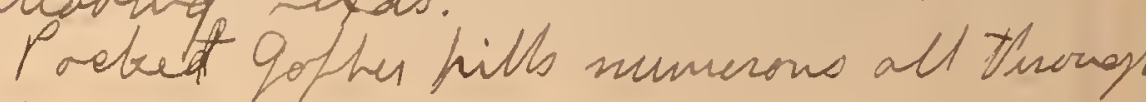
and. Hu. 
7Ft.12 Kasbed Kannas City of dayliegtt. A chen, frasty nosnisy. Kupuatur 29 at sumise. Hegin to se mittius $x$ ovneoats. Here are the fisst grain elevalars 2 low sum sines intring Weatern Net., fume, 1889.

Lft Kanras Qity of 8 A.M., curaced the Misooni R. Thenes 1. S. Oo Guiney. lde. The timber aloro the Misarni $k$. is mice lite that of Nimuceta. Lrouwood, large elms, bassword, buch, mafl, ash, t hiery an common. Afth leaving the timpter of the cives. he ast on solling praisis, with Naok soif, malt ploveghs, ofin farms. Thifty toum are clove ticethor on the R.R. The faces of Seandiravion. T Gurwans nidonimant + the color elment is seares. 2 left the Muxicans in San Antoni.

There is timber along the streams whish are numeruss. A thin stim of iee covered the fords in thomorning wot was X gres byou night. hoched Arimer at darte is lad to wait ill $2: 40$ in the sioring for the ham to Buslivation, Yowa. Large flocks of erows were cornmon all daly, other birds sem to ve searre. 
ch.s Lift Gimey at 2 A.M. into Rustingtor dowd at daylight. hain to Dimuopalis. A oold, prosty warning, ro anow. no ree in sives but the ground slightly foren. Made a mistakb in the train $\checkmark$ have to wait till toworwow sight. clould uf 5 got wasm o a drizgle of rain in evering o all ingtt.

" 14 An eveslasting long day tnothing tods. dank but rot cold. Got. startid. ot last-7:30 P.M. There are lots of Passer dowestien in kity.

15 At daylight we an near Waued, Mim., o littl, sfaits of arow are bying in slady pacen. It is frosth th air fiels pusht niffich. Lnow inereases in extent $r$ lat Uessians function, wher we strik the ST.P.M.T. O. R.R. it eovers hall the ground $t$ in tho words is allow tho ground. At nimueaplis it is the same o ouly a bittle more of Elk Rives. Had to wait at thimeafolis 
till 4 P.M. + noched Elk kiver at 6. Th winter hur bas veeu unusually wasm + there is much bare gpourd. 


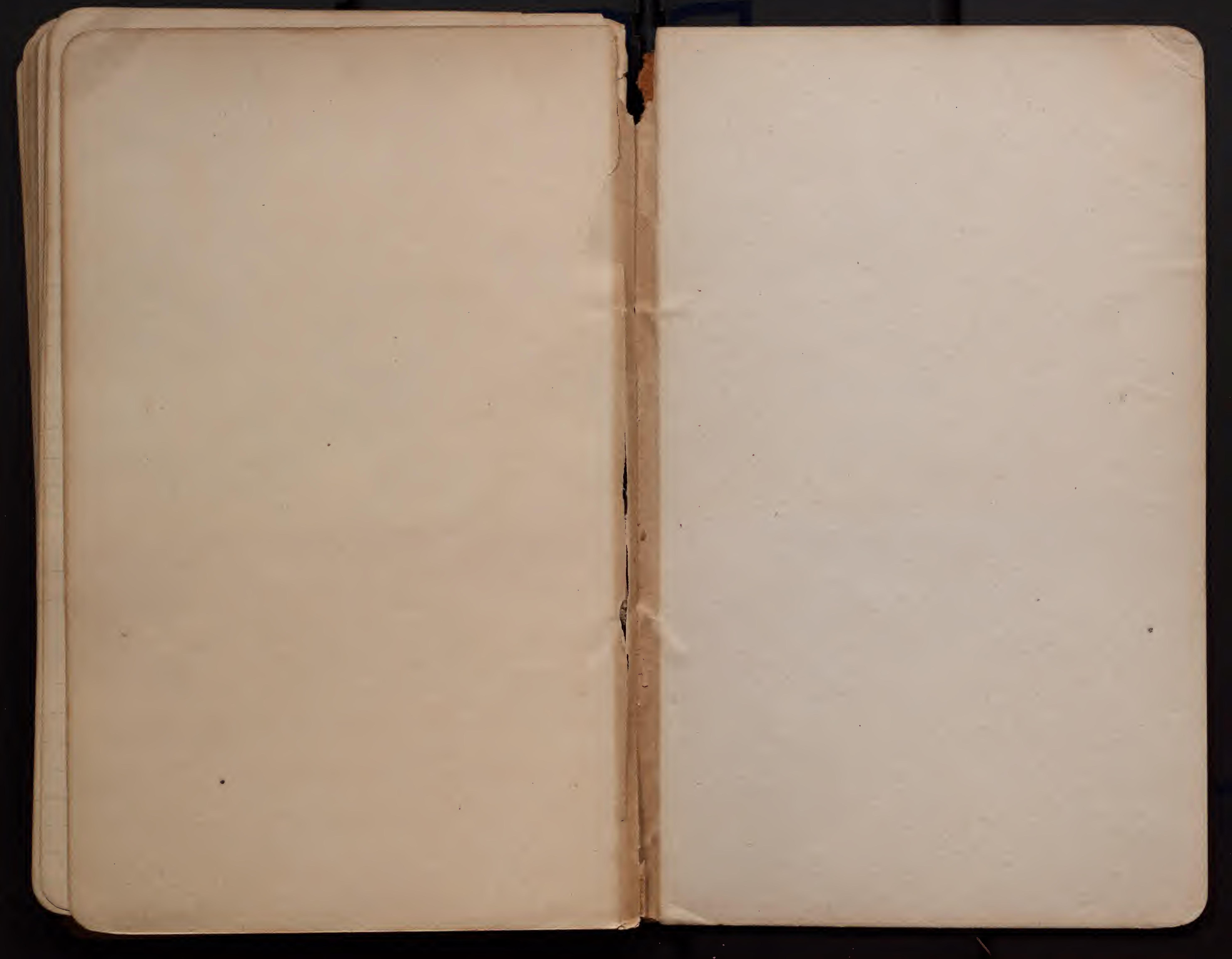


